Available online at GSC Online Press Directory

GSC Biological and Pharmaceutical Sciences

e-ISSN: 2581-3250, CODEN (USA): GBPSC2

Journal homepage: https://www.gsconlinepress.com/journals/gscbps

(CASE STUDY)

\title{
A case of cruelty in dog and its management
}

\author{
Bosha J. A. ${ }^{1,}{ }^{*}$, Tion M. T. ${ }^{2}$ and Agbo J. O. ${ }^{1}$ \\ ${ }^{1}$ Department of Veterinary Physiology, Pharmacology and Biochemistry, University of Agriculture Makurdi, Benue State, \\ Nigeria. \\ ${ }^{2}$ Department of Veterinary Medicine, University of Agriculture Makurdi, Benue State, Nigeria.
}

Publication history: Received on 26 April 2018; accepted on 01 June 2018

Article DOI: https://doi.org/10.30574/gscbps.2018.3.3.0034

\begin{abstract}
Cases of animal cruelty are on the increase all over the world. Cruelty in dogs is mostly perpetrated by dog owners and those in the neighborhood. This could be intentional or unintentional. Studies have suggested that persons who are cruel to animals are linked to one form of violence or the other. Adequate legislation, education and psychological counseling of people involved in acts of cruelty to animals are some of the approaches to curb violence to animals. The case report presented here centers on an injury inflicted on a dog that strayed from the home for 5 days and how the wound was managed.
\end{abstract}

Keywords: Cruelty; Wound management; Dog owners; Psychological counseling

\section{Introduction}

Animal cruelty is a socially unacceptable behavior that intentionally causes unnecessary pain, suffering, distress to and or death of an animal [1]. Failure to provide adequate food, shelter, water or veterinary care usually due to ignorance is the most common type of animal cruelty around the world [2]. Some dog owners intentionally withhold food or water [3], giving rise to animals going out to fend for themselves. Most dogs pick up injuries in their bid to scavenge. Animal cruelty has been linked to variety of crimes including violence against other people, property crimes and drug or disorderly conduct and offenses [4]. Fifty (50) violent and 50 non-violent inmates were studied to determine if and how animal cruelty was associated with their development and behavior. Statistically significant portion of the offenders had committed acts of animal cruelty as indicated by the result [5].

\section{Case report}

A 2 Year old male mongrel dog, brown in color with black stripe was presented to the Small Animal Clinic of the Veterinary Teaching Hospital, University of Agriculture Makurdi on 17th of November, 2014 with the chief complaint of wound on the dorsum (Fig. 1A). History revealed that the dog left the house for 5 days and returned with wounds on the back. There was a massive wound on the dorsum with necrotic skin patches attached at some areas. The dog shows groaning signs of pains. Other clinical findings on presentation and on day 2 and 5 are shown in Table 1.

\footnotetext{
${ }^{*}$ Corresponding author

E-mail address: agbojoseph222@ gmail.com
}

Copyright (C) 2018 Author(s) retain the copyright of this article. This article is published under the terms of the Creative Commons Attribution Liscense 4.0. 


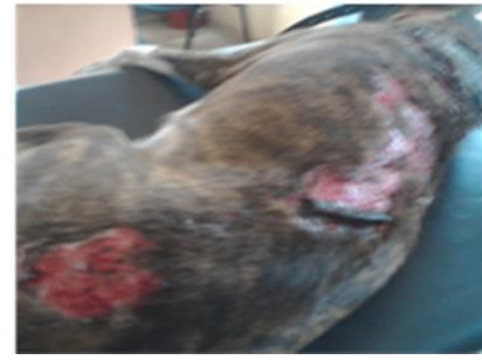

A

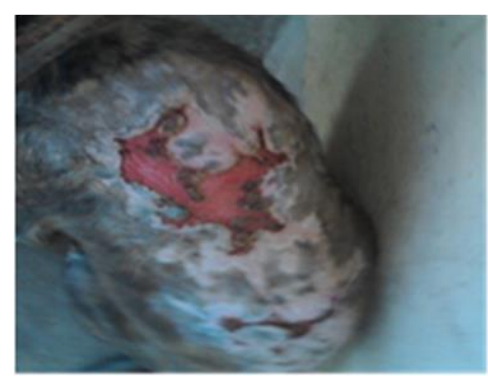

D

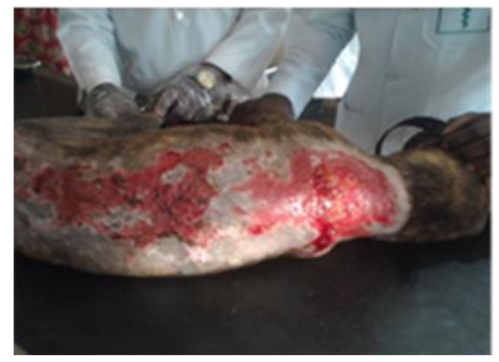

B

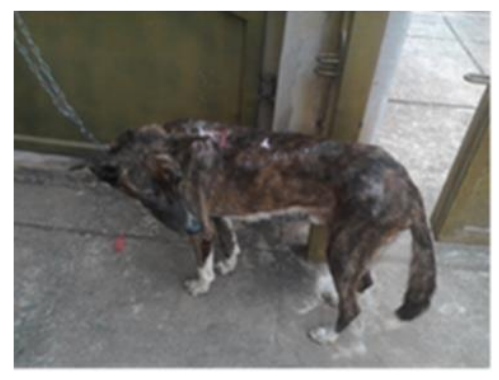

$E$

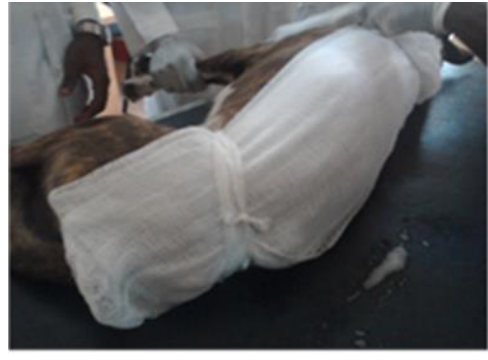

C

Figure 1 Photograph of $\operatorname{dog}(\mathrm{A}$ - at the time of presentation, B- at post debridement, C- during dressing, D- during recovery, E- after recovery).

Table 1 Clinical observation of dog

\begin{tabular}{lcccc}
\hline Parameters & \multicolumn{2}{c}{ Observations } & Normal values \\
& On presentation & Day 2 & Day 5 & - \\
\hline Weight (kg) & 20 & 20 & 20 & $90-120$ \\
Pulse rate (beats/min) & 110 & 44 & 72 & $90-120$ \\
Heart rate (beats/min) & 120 & 60 & 86 & $15-30$ \\
Resp. rate (cycle/min) & 32 & 30 & 29 & $38.5-39.5$ \\
Temperature (ํㅡ) & 41.5 & 38.6 & 38.6 & Pink \\
Mucous membrane & Pink & Pink & Pink &
\end{tabular}

The dog was premedicated using atropine $(0.05 \mathrm{mg} / \mathrm{kg}, \mathrm{i} . \mathrm{m})$ and sedated using xylazine ( $3 \mathrm{mg} / \mathrm{kg}$, i.m). The site of injury (Fig. 1A) was shaved using a razor blade. Necrotic areas were debrided to create fresh wound. Hydrogen peroxide (6 \% $\mathrm{w} / \mathrm{v}$ ) was diluted with equal volume of water and used to mop the surface (Fig. 1B). Penicillin ointment (5000 i.u/g) was liberally applied topically on the wound, thereafter gauze was used to cover the entire wound surface (Fig. 1C). Charmil skin spray (a multi-action skin gel containing Azadirachta indica, Cedrus deodora, and Pongamia pinnata) was applied over the surface of the gauze. The gauze was fastened to both ends and a plastic collar attached round the neck to prevent the dog from biting or removing the gauze to prevent exposing or contamination of the wound (Fig. 1C).

Penstrep® (200 mg of penicillin G and $250 \mathrm{mg}$ of dihydrostreptomycin) was administered for 5 days at a dose of $1 \mathrm{ml} /$ $25 \mathrm{~kg}$ to prevent secondary bacterial infection. Piroxicam $(0.3 \mathrm{mg} / \mathrm{kg})$ a non-steroidal anti-inflammatory, analgesic and antipyretic agent was administered for 3 days. The dog was hospitalized for close monitoring and the dressing of the wound was carried out every other day. The dog during recovery is shown in Fig. 1D. 


\section{Discussion}

The case report has shown the extent of damage that was inflicted on a dog (Fig. 1A and 1B). The dog was reported to have left the house for 5 days and was presented to the clinic upon its return. Dogs that are not adequately cared for have the tendency of leaving the house in search of food [6]. This could result in their been attacked or injured by people in the neighborhood. In this case, the owner of the dog travelled and left the dog in the care of the house help who did not care much for the welfare of the dog warranting it to leave the house without his knowledge for a period of five days. The house help did not know the where about of the dog, neither was he able to describe what has happened to it. If this dog was well cared for it should not have gone out of the house for such a long period of time. The nature of the injury suggested to us that the dog must have been attacked with a corrosive or hot liquid. This observation is based on the depth and edges of the wound.

Cruelty to animals by dog owners can result in increased number of stray dogs which is a major source of concern in the epidemiology of rabies [7]. In developing countries such as Nigeria, many people keep dogs for various reasons like pets, security or haunting without adequate care [8]. Most of the times, these dogs are left to fend for themselves. This makes them to roam around as stray dogs.

Studies have shown that people who are cruel to animals have tendencies for crime [4]. Children who are cruel to animals disproportionally tend to be violent to people later in life [9]. Case histories of serial killers and mass murders suggest that many were cruel to animals during childhood [9]. It is argued that cruelty to animals in the family tend to be associated with domestic violence, child abuse and elder abuse [10]. From the fore going, it is important that the general public should take the issue of cruelty to animals very seriously because cruelty to animals is linked to cruelty to humanity.

In combating animal cruelty effectively, the government, individuals and non-governmental organizations (NGO) should be actively involved in education and sensitization of the general public. The government creates and implements the law, the individuals ensures reporting of cases of animal cruelty, while the NGOs will carry out campaigns on animal welfare [11].

\section{Conclusion}

Animal welfare studies should be taken seriously, given that cruelty to animals is a form of violence and its studies will help give insight into other social vices. The affected dog recovered fully after four weeks.

\section{Compliance with ethical standards}

\section{Acknowledgments}

The authors acknowledge the contributions of the staff of the small animal clinic of the Veterinary Teaching Hospital, University of Agriculture, Makurdi, Benue State Nigeria in taking care of the dog as an inpatient.

\section{Disclosure of conflict of interest}

The authors declare that they have no competing interests.

\section{References}

[1] Ascione FR. (1993). Children who are cruel to animals: A review of research and implications for developmental psychopathology, Anthrozoos, 6, 226-247.

[2] Randour ML. (2004). Including animal cruelty as a factor in assessing risk and designing interventions, Conference proceedings, Persistently Safe Schools, The National Conference of the Halmilton Fish Institute on School and Community Violence, Washington DC.

[3] Lockwood R. (2006). Counting cruelty: challenges and opportunities in assessing animal abuse and neglect in America, in International Handbook of Theory and Research on Animal Abuse and Purdue University Press.

[4] Flynn CP. (2000). Woman's best friend: pet abuse and the role of companion animals in the lives of battered women. Violence against Women, 6, 162-177. 
[5] Merz-Perez L and Heide KM. (2004). Animal Cruelty: Pathways to violence against people. Rowman and Littlefield Pub. Inc. Lanham.

[6] Lyu P. Proposal on solutions to stray dog problem in American cities. Journal of Political Science and Public Affairs, 3, 175.

[7] Kasempimolporn S, Sichanasai B, Saengseesom W, Puempumpanich S and Sitprija V. (2008). Stray dogs in Bangkok, Thailand: rabies virus infection and rabies antibody prevalence. Developmental Biology, 131, 137-43.

[8] Aiyedun JO and Olugasa BO. (2012). Identification and analysis of dog use, management practices and implications for rabies control in Ilorin, Nigeria. Sokoto Journal of Veterinary Science, 10, 1-6.

[9] Broidy LM, Nagin DS, Tremblay RE, Bates JE, Brame B, Dodge K, Fergusson D, Howard J, Loeber R, Laird R, Lynam D, Mofitt T, Petitt GS and Vatario F. (2003). Development trajectories of childhood disruptive behavior's and adolescence delinquency: A Six Site across National Replication. Development and Psychopathology, 39, 222-245.

[10] Marie LP and David PF (2007). Cruelty to animals and violence to people, Victims and Offenders, 2(1), 21-43.

[11] Mogbo TC, Oduah FN, Okeke JJ, Ufele AN and Nwankwo OD. (2013). Animal Cruelty: A Review Journal of Natural Science and Research, 3(8), 94-98.

\section{How to cite this article}

Bosha JA, Tion MT and Agbo JO. (2018). A case of cruelty in dog and its management. GSC Biological and Pharmaceutical Sciences, 3(3), 06-09. 